\title{
Good Corporate Governance Sebagai Pemoderasi Pengaruh Profitabilitas dan Corporate Social Responsibility pada Nilai Perusahaan
}

\author{
I Putu Indra Wijaya ${ }^{1}$ \\ Ni Gusti Putu Wirawati ${ }^{2}$ \\ ${ }^{1,2}$ Fakultas Ekonomi dan Bisnis Universitas Udayana (Unud), Bali, Indonesia \\ e-mail: mahasiswajarangpulang@gmail.com
}

\begin{abstract}
ABSTRAK
Tujuan penelitian ini untuk mendapatkan bukti empiris mengenai GCG sebagai pemoderasi pengaruh profitabilitas dan CSR pada nilai perusahaan seluruh perusahaan yang terdaftar di BEI periode 2013-2016. Hasil penelitian menemukan bahwa profitabilitas dan CSR berpengaruh positif pada nilai perusahaan. GCG mampu memperkuat pengaruh CSR pada nilai perusahaan, namun GCG tidak mampu memoderasi pengaruh profitabilitas pada nilai perusahaan. Hasil penelitian ini diharapkan mampu memberikan informasi bagi perusahaan terkait pentingnya meningkatkan profitabilitas, pengungkapan CSR dan penerapan GCG sehingga nantinya dapat meningkatkan nilai perushaan. Hasil penelitian ini diharapkan mampu memberikan informasi bagi pihak-pihak yang berpekentingan sebagai dasar pengambilan keputusan investasi.
\end{abstract}

Kata kunci: Nilai perusahaan, profitabilitas, CSR, GCG.

\begin{abstract}
The purpose of this study is to obtain empirical evidence regarding GCG as a moderating effect of profitability and CSR on the value of the companies of all companies listed on the Stock Exchange for the period 2013-2016. The results of the study found that profitability and CSR had a positive effect on firm value. GCG is able to strengthen the influence of CSR on corporate value, but GCG is not able to moderate the effect of profitability on company value. The results of this study are expected to be able to provide information for companies regarding the importance of increasing profitability, CSR disclosure and GCG implementation so that later it can increase the value of the company. The results of this study are expected to be able to provide information for interested parties as a basis for making investment decisions.
\end{abstract}

Keywords: Firm value, profitability, CSR, GCG

\section{PENDAHULUAN}

Memasuki pertengahan tahun 2015 terjadi pelemahan perekonomian global. Pelemahan perekonomian disebabkan oleh Krisis Yunani, kenaikan suku bunga The Fed serta pelemahan perekonomian di China. Berawal dari Yunani yang gagal membayar cicilan utang dan terancam bangkrut. Ancaman tersebut juga mengancam perekonomian Jerman sebagai kreditor terbesar Yunani, yang 
I Putu Indra Wijaya dan Ni Gusti Putu Wirawati. Good ...

selanjutnya akan memengaruhi negara-negara di Benua Eropa. Amerika Serikat juga akan mengalami perlambatan pertumbuhan ekonomi karena sepuluh persen ekspornya diserap oleh negara di Benua Eropa. China juga akan mengalami perlambatan ekonomi, karena Amerika Serikat akan mengurangi impornya. China sebagai negara dengan perekonomian terkuat di Benua Asia akan memengaruhi perekonomian Indonesia. Kurs rupiah berpotensi tertekan dan ekonomi terancam semakin melambat karena China mengalami perlambatan ekonomi. Krisis Yunani juga berpotensi melemahkan nilai tukar rupiah terhadap dolar (www.katadata.co.id).

Bank Sentral Amerika Serikat, yaitu TheFed menaikkan suku bunga yang menyebabkan nilai dolar menguat. Perekonomian Indonesia yang lemah menyebabkan kurs rupiah tertekan dan melemah terhadap dolar, efek dari kenaikan suku bunga The Fed menyebabkan para investor melarikan dolar mereka kembali ke negaranya sehingga membuat dolar menguat. Ditambah dengan menurunnyaperekonomian China akibat dari melemahnya harga-harga komoditas barang di beragam mancanegara yang menyebabkan mengalami defisit neraca perdagangan. Hal ini diperparah dengan rencana The Fed menaikkan tingkat suku bunganya lagi pada akhir bulan ini atau bulan depan (www.kompasiana.com).

Krisis ekonomi global yang berdampak di Indonesia menyebabkan pertumbuhan ekonomi Indonesia terus melambat pada tahun 2015. Berikut data dari Badan Pusat Statistik mengenai pertumbuhan ekonomi Indonesia tahun 20132017 yang ditunjukkan pada Gambar 1 sebagai berikut. 


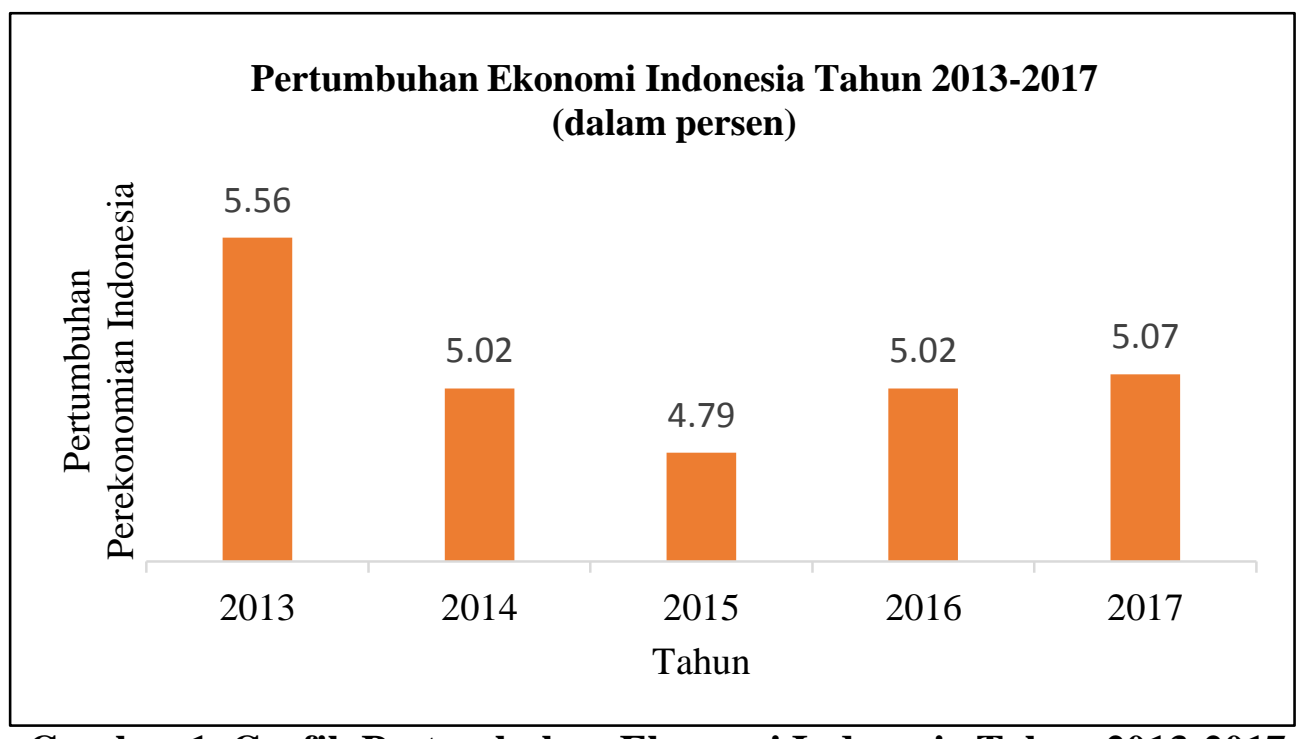

Gambar 1. Grafik Pertumbuhan Ekonomi Indonesia Tahun 2013-2017

Sumber: Badan Pusat Statistik, 2018

Perekonomian Indonesia yang melemah dan diikuti oleh dijualnya sahamsaham perusahaan Indonesia oleh investor pada tahun 2015 menggerakkan pemerintah untuk membuat kebijakan ekonomi yang mengatur kemudahan berinvestasi dan mendirikan usaha khususnya investor asing yang ingin berinvestasi di Indonesia. Sebuah studi oleh Eurocham menyebutkan tingkat kepercayaan investor Eropa kepada Indonesia menurun karena masalah regulasi, birokrasi dan kebijakan ketenagakerjaan saat berinvestasi di Indonesia (www.bbc.com). Kondisi tersebut secara tidak langsung memengaruhi nilai perusahaan, karena nilai perusahaan dilihat dari kemakmuran para pemegang saham yang diukur melalui harga saham di pasar modal. Berikut data mengenai pergerakan nilai perusahaan pada seluruh sektor di Bursa Efek Indonesia (BEI) periode 2014-2015 yang ditunjukkan pada Tabel 1 sebagai berikut. 
Tabel 1.

Rasio Nilai Perusahaan Berbagai Sektor di BEI Periode 2014-2015 Nilai Perusahaan

\begin{tabular}{lcc}
\multicolumn{1}{c}{ Sektor } & Nilai Perusahaan & Tahun \\
& $\mathbf{2 0 1 4}$ & $\mathbf{2 0 1 5}$ \\
\hline Pertanian & 4,70 & 3,60 \\
Pertambangan & 2,09 & 1,16 \\
Industri Dasar dan Kimia & 0,60 & 2,01 \\
Aneka Industri & 1,12 & 1,23 \\
Barang Konsumsi & 5,38 & 2,22 \\
Properti, Real Estat dan & 2,36 & 2,04 \\
Konstruksi Bangunan & & \\
Infrastruktur, Utilitas dan & 1,36 & 1,93 \\
Transportasi & 1,55 & 1,65 \\
Keuangan & 2,22 & 2,17 \\
Perdagangan, Jasa dan & & \\
Investasi & &
\end{tabular}

Sumber: www.idx.co.id, 2018

Tabel 1 menunjukkan nilai perusahaan seluruh sektor di BEI periode 20142015 yang diproksikan melalui Price to Book Value (PBV). PBV merupakan salah satu rasio yang dapat digunakan untuk menghitung nilai perusahaan. Berdasarkan Tabel 1.1 dapat dilihat bahwa sebagian besar sektor perusahaan di BEI merasakan dampak dari krisis ekonomi global yang berpengaruh terhadap turunnya nilai perusahaan pada tahun 2015. Seperti nilai perusahaan sektor barang konsumsi mengalami penurunan yang signifikan di tahun 2015, awalnya PBV sektor barang konsumsi bernilai 5,38 di tahun 2014 kemudian turun menjadi 2,22 di tahun 2015 . Begitu pula dengan beberapa sektor perusahaan lainnya yang mengalami penurunan nilai perusahaan di tahun 2015. Tren yang berbeda ditunjukkan pada beberapa sektor yang mengalami peningkatan nilai perusahaan. Sektor keuangan merupakan salah satu sektor yang mengalami peningkatan nilai perusahaan pada tahun 2015. Berdasarkan fenomena tersebut peneliti tertarik untuk melakukan penelitian terhadap nilai perusahaan. 
Nilai perusahaan merupakan persepsi investor terhadap tingkat keberhasilan perusahaan untuk dapat memberikan kemakmuran pemegang saham secara maksimum dengan meningkatnya harga saham perusahaan(Indasari, 2018). Tingginya nilai suatu perusahaan akan membuat investor yakin terhadap keberlangsungan dan prospeknya di masa mendatang. Terdapat beberapa faktor yang dapat memengaruhi nilai perusahaan, yaitu faktor keuangan dan non keuangan. Salah satu faktor keuangan yang dapat memengaruhi nilai perusahaan adalah profitabilitas dan salah satu faktor non keuangan yang dapat memengaruhi nilai perusahaan yaitu pengungkapan Corporate Social Responsibility (CSR).

Analisis profitabilitas merupakan faktor yang sangat penting dalam evaluasi kinerja semua perusahaan selama periode tertentu (Warrad \& Nassar, 2017). Profitabilitas adalah kemampuan suatu perusahaan untuk menghasilkan laba selama periode tertentu. Perusahaan dengan tingkat profitabilitas yang lebih tinggi akan memberikan peluang return yang lebih tinggi pula bagi para investor. Profitabilitas yang tinggi menunjukkan prospek perusahaan yang baik, sehingga investor akan merespon positif sinyal tersebut dan pada akhirnya dapat meningkatkan nilai perusahaan (Puspita, 2018). Sejalan dengan hasil penelitian yang dilakukan Permana(2017) dan Rahman dkk. (2017) menemukan bahwa profitabilitas berpengaruh positif pada nilai perusahaan. Hasil penelitian tersebut bertentangan dengan hasil penelitian Malik (2018) dan Triyana(2017) yang menunjukkan bahwa profitabilitas tidak berpengaruh pada nilai perusahaan.

Beberapa tahun terakhir, Corporate Social Responsibility (CSR) telah mendapatkan perhatian yang semakin besar untuk investasi dalam perusahaan 
I Putu Indra Wijaya dan Ni Gusti Putu Wirawati. Good ...

yang bertanggung jawab secara sosial. CSRadalah tanggung jawab perusahaan terhadap sosial dan lingkungan atas operasi bisnis yang dilakukan oleh perusahaan berdasarkan konsep triple bottom lines, yaitu profit, people, planet (Maqbool \& Zameer, 2018). Pelaksanaan CSR oleh perusahaan merupakan sinyal positif bagi investor karena investor cenderung lebih tertarik dengan perusahaan yang memiliki citra positif di mata masyarakat luas agar dapat memastikan keberlangsungan perusahaan (Retno, 2017). Hal ini menunjukkan bahwa nilai perusahaan dapat ditingkatkan dengan menyelaraskan bisnis perusahaan melalui program CSR yang efektif (Jitmaneeroj, 2018). Sejalan dengan hasil penelitian yang dilakukan Citra (2017) dan Sulistyaningsih dkk. (2017) menemukan bahwa CSR berpengaruh positif pada nilai perusahaan. Hasil penelitian tersebut bertentangan dengan hasil penelitian Inastri (2017) dan Kusumayanti (2016) menunjukkan bahwa CSR tidak berpengaruh pada nilai perusahaan.

Adanya inkonsistensi hasil penelitian sebelumnya mengenai pengaruh profitabilitas dan CSRpada nilai perusahaan menjadi dasar dan motivasi untuk memasukkan Good Corporate Governance (GCG) sebagai variabel pemoderasi. GCGadalah sistem yang menjadi dasar suatu proses, mekanisme dalam mengelola perusahaan yang baik berdasarkan peraturan, perundang-undangan dan etika berusaha agar timbul kepercayaan terhadap perusahaan dengan menciptakan iklim usaha yang sehat yang dapat meningkatkan nilai tambah perusahaan dalam jangka panjang serta pertanggungjawaban kepada pemangku kepentingan (stakeholder) (Putri \& Ulupui, 2017: 4). 
GCG akan meningkatkan kualitas tata kelola perusahaan dan meningkatkan akuntabilitas perusahaan kepada pemegang saham sekaligus memaksimalkan nilai pemegang saham atau pemangku kepentingan lainnya (Krenn, 2016). Menurut Heder (2017) diterapkannya GCG maka manajemen perusahaan akan tertata dengan baik sehingga dapat meningkatkan profitabilitas perusahaan itu sendiri dan dengan meningkatnya kinerja keuangan yang ditunjang dari profitabilitas perusahaan, maka menjadi daya tarik bagi investor sehingga akan meningkatkan nilai perusahaan. Implementasi CSR merupakan salah satu wujud pelaksanaan prinsip GCG. Melalui penerapan GCG perusahaan diharapkan dapat meningkatkan kinerjanya, sehingga kegiatan yang berkaitan dengan CSR juga mengalami peningkatan. Semakin baik manajemen dalam mengelola perusahaan menyebabkan pengungkapan CSR semakin baik, sehingga nilai perusahaan semakin tinggi (Retno, 2017).

Perusahaan dijalankan sesuai dengan norma-norma, nilai dan keyakinan di masyarakat yang berlaku agar mendapatkan legitimasi (Nègre et al., 2017). Legitimasi penting bagi perusahaan karena berhubungan dengan kelangsungan hidup perusahaan. Ketika terjadi ketidakselarasan nilai sosial dan norma perusahaan, maka perusahaan akan dapat kehilangan legitimasinya, yang selanjutnya akan mengacam kelangsungan hidup perusahaan. Perusahaan yang mampu memenuhi kontrak sosial maka keberadaan perusahaan akan direspon positif oleh masyarakat. Legitimasi dapat dikatakan sebagai manfaat atau sumber potensial bagi perusahaan untuk bertahan hidup. Legitimasi ini akan meningkatkan reputasi perusahaan yang pada akhirnya akan berpengaruh pada 
I Putu Indra Wijaya dan Ni Gusti Putu Wirawati. Good ...

nilai perusahaan (Retno, 2017). Semakin besar perhatian perusahaan terhadap lingkungan sekitar maka semakin tinggi kepedulian masyarakat terhadap kinerja mereka. Mekanisme CSR adalah mekanisme yang dalam praktiknya bertanggung jawab terhadap masyarakat secara sosial. Sejalan dengan teori legitimasi yang menjelaskan bahwa perusahaan memiliki kontrak dengan masyarakat untuk melakukan kegiatannya berdasarkan nilai-nilai justice dan bagaimana perusahaan menanggapi berbagai kelompok kepentingan untuk melegitimasi tindakan perusahaan (Oktaviana, 2017).

Profitabilitas adalah kemampuan perusahaan dalam menghasilkan laba selama periode tertentu dan memberikan gambaran tentang tingkat efektivitas manajemen dalam melaksanakan kegiatan operasinya. Semakin besarnya laba yang diperoleh perusahaan bisa menarik perhatian investor karena dianggap memiliki prospek yang baik kedepanya. Setiap perusahaan akan selalu meningkatkan profitabilitasnya, karena semakin tinggi tingkat profitabilitas suatu perusahaan maka kelangsungan hidup perusahaan tersebut akan lebih terjamin (Malik, 2018).

Semakin tinggi profitabilitas perusahaan akan memberikan sinyal positif kepada investor. Tingginya profitabilitas yang dimiliki sebuah perusahaan akan menarik minat investor untuk menanamkan modalnya diperusahaan maka hal itu dapat meningkatkan nilai perusahaan. Penilitian sebelumnya dilakukan oleh Puspita (2018) menyatakan bahwa profitabilitas berbengaruh positif pada nilai perusahaan karena profitabilitas yang tinggi menunjukkan prospek perusahaan yang baik, sehingga investor akan merespon positif sinyal tersebut dan pada 
akhirnya dapat meningkatkan nilai perusahaan. Sejalan dengan hasil penelitian yang dilakukan Indasari (2018), Dewi (2018), Malino (2017) dan Rahman et al. (2017) bahwa profitabilitas berpengaruh positif pada nilai perusahaan. Berdasarkan teori dan hasil penelitian tersebut dapat diajukan hipotesis sebagai berikut.

$\mathrm{H}_{1}$ : Profitabilitas berpengaruh positif pada nilai perusahaan.

Menurut WBCSD CSR adalah komitmen berkelanjutan oleh perusahaan untuk berperilaku etis dan berkontribusi terhadap pembangunan ekonomi sambil meningkatkan kualitas hidup tenaga kerja dan keluarga mereka serta masyarakat setempat dan masyarakat luas (www.gaega.bg). CSR adalah tanggung jawab perusahaan terhadap sosial dan lingkungan atas operasi bisnis yang dilakukan oleh perusahaan berdasarkan konsep triple bottom lines. Saat ini investor tidak hanya melihat tingkat keuntungan suatu perusahaan saja dalam pengambilan keputusan investasi melainkan melihat citra perusahaan. Pelaksanaan CSR oleh perusahaan merupakan sinyal positif bagi investor karena investor cenderung lebih tertarik dengan perusahaan yang memiliki citra positif di mata masyarakat luas agar dapat memastikan keberlangsungan perusahaan.

Penelitian sebelumnya dilakukan oleh Sidhoum \& Serra (2017) menyatakan bahwa CSR berpengaruh positif pada nilai perusahaan. Semakin banyak item pengungkapan sosial yang diungkapkan bila diiringi dengan kualitas pengungkapan yang semakin baik, maka dapat meningkatkan nilai perusahaan. Perusahaan yang memiliki komitmen CSR dalam jangka panjang akan mengalami peningkatan harga saham yang lebih signifikan. Hasil penelitiantersebut sejalan 
I Putu Indra Wijaya dan Ni Gusti Putu Wirawati. Good ...

dengan penelitian yang dilakukan Armika (2018), Citra (2017), Wulansari (2017) dan Ramadhani dkk. (2017) bahwa CSR berpengaruh positif pada nilai perusahaan. Berdasarkan teori dan hasil penelitian tersebut dapat diajukan hipotesis sebagai berikut.

$\mathrm{H}_{2}$ : Corporate Social Responsibility berpengaruh positif pada nilai perusahaan.

Profitabilitas merupakan salah satu aspek penting yang dilihat dalam laporan keuangan. Profitabilitas yang tinggi diasumsikan dapat meningkatkan nilai perusahaan oleh beberapa pihak yang berkepetingan. Terdapat dua pihak yang berkepentingan dengan perusahaan, yaitu prinsipal dan agen. Dua pihak tersebut memiliki kepeningan yang berbeda, di mana prinsipal menginginkan profit perusahaan digunakan semaksimal mungkin untuk memakmurkan pemegang saham, sementara agen menginginkan laba perusahan untuk kepentingan pribadi semata yang dimana kedua kepentingan ini dapat menimbulkan konflik keagenan sesuai dengan pernyataan dalam teori keagenan (Jensen \& Meckling, 1976).

GCG dapat mengurangi potensi konflik keagenan antara prinsipal dan agen. Penelitian sebelumnya dilakukan oleh Heder (2017) menyatakan bahwa diterapkannya GCG maka manajemen perusahaan akan tertata dengan baik sehingga dapat meningkatkan profitabilitas perusahaan itu sendiri dan dengan meningkatnya kinerja keuangan yang ditunjang dari profitabilitas perusahaan, maka menjadi daya tarik bagi investor sehingga akan meningkatkan nilai perusahaan.Hasil penelitian tersebut sejalan dengan penelitian yang dilakukan oleh Mawati dkk. (2017), Maulana (2016), Imron dkk. (2014) dan Muliani dkk. 
(2014) bahwa GCGmemperkuat pengaruh profitabilitas pada nilai perusahaan. Berdasarkan teori dan hasil penelitian tersebut dapat diajukan hipotesis sebagai berikut.

$\mathrm{H}_{3}$ : Good Corporate Governancememperkuat pengaruh profitabilitas pada nilai perusahaan.

CSR semakin menyedot perhatian kalangan pelaku bisnis sejak regulasi pemerintah memasukkan ketentuan tersendiri mengenai CSR dalam UndangUndang Nomor 40 Tahun 2007. Pentingnya aktivitas CSR serta regulasi yang mengatur tentang kewajiban perusahaan untuk melakukan CSR menyebabkan perusahaan lebih memerhatikan aktivitas tanggung jawab sosialnya untuk meningkatkan nilai perusahaan (Fiona, 2017). CSR dapat memberikan kontribusi terhadap kinerja keuangan karena dalam pengambilan keputusan, perusahaan harus mempertimbangkan berbagai masalah sosial dan lingkungan jika perusahaan ingin memaksimalkan hasil keuangan jangka panjang yang nantinya dapat meningkatkan nilai perusahaan (Kemala dkk., 2016).

Implementasi CSR merupakan salah satu wujud pelaksanaan prinsip GCG. Melalui pelaksanaan GCG maka mendorong perusahaan untuk terus meningkatkan aktivitas CSR perusahaan sehingga citra perusahaan meningkat. Semakin baik manajemen dalam mengelola perusahaan menyebabkan pengungkapan CSR semakin baik, sehingga nilai perusahaan semakin tinggi (Retno, 2017). Melalui penerapan GCG perusahaan diharapkan dapat meningkatkan kinerjanya, sehingga kegiatan yang berkaitan dengan CSR juga mengalami peningkatan. Penelitian yang dilakukan Kemala dkk. (2016) menyatakan bahwa GCG dapat memoderasi hubungan CSR terhadap nilai 
I Putu Indra Wijaya dan Ni Gusti Putu Wirawati. Good ...

perusahaan. Sejalan dengan hasil penelitian Fiona (2017), Latupono (2015), Isbandi (2014) dan Astiyani (2014) menemukan bahwa GCG dapat memperkuat pengaruh pengungkapan CSR pada nilai perusahaan. Berdasarkan teori dan hasil penelitian tersebut dapat diajukan hipotesis sebagai berikut.

$\mathrm{H}_{4}$ : Good Corporate Governancememperkuat pengaruh Corporate Social Responsibility pada nilai perusahaan.

\section{METODE PENELITIAN}

Lokasi penelitian ini dilakukan pada seluruh perusahaan yang terdaftar di Bursa Efek Indonesia (BEI) periode 2013-2016. Objek penelitian ini adalah nilai perusahaan yang dipengaruhi profitabilitas, Corporate Social Responsibility dan Good Corporate Governance pada seluruh perusahaan yang terdaftar di BEI periode 2013-2016. Variabel dependen dalam penelitian ini adalah nilai perusahaan (Y). Variabel independen dalam penelitian ini adalah profitabilitas $\left(\mathrm{X}_{1}\right)$ dan Corporate Social Responsibility $\left(\mathrm{X}_{2}\right)$. Variabel moderasi dalam penelitian ini adalah Good Corporate Governance (M).

Nilai perusahaan diukur dengan menggunakan Price to Book Value (PBV). PBV merupakan rasio antara harga per saham dibagi nilai buku per saham (Ross et al., 2016: 66). Rumus perhitungan PBV sebagai berikut.

$$
\text { PBV }=\frac{\text { Harga Saham }}{\text { Book Value Per Share }}
$$

$$
\text { Book Value Per Share }=\frac{\text { Modal }}{\text { Jumlah Saham Beredar }}
$$

Profitabilitas diukur dengan menggunakan Return On Asset (ROA). ROA merupakan rasio antara laba bersih dibagi total aset (Ross et al., 2016: 64). 
Semakin besar ROA sebuah perusahaan akan menunjukkan kinerja keuangan yang semakin baik, karena tingkat pengembalian (return) semakin besar. Rumus perhitungan ROA sebagai berikut.

$$
\mathrm{ROA}=\frac{\text { Laba Bersih }}{\text { Total Aset }} \times 100 \%
$$

Pengungkapan CSR diukur menggunakan Corporate Social Responsibility Disclosure Index (CSRDI). Kemudian CSRDI diukur menggunakan standar Global Reporting Initiative (GRI). Berdasarkan GRI versi terbaru yaitu GRI-G4.

$$
\operatorname{CSRDI}_{\mathrm{j}}=\frac{\sum X i j}{n}
$$

Keterangan:

$\mathrm{CSRDI}_{\mathrm{j}} \quad$ : Corporate Social Responsibility Disclosure Index

$\sum X \mathrm{Xjj} \quad:$ Jumlah Pengungkapan

n $\quad$ : Item Pengungkapan CSRDI

GCG diproksikan denganCorporate Governance Perception Index (CGPI) yang dikeluarkan oleh The Indonesian Institute for Corporate Governance (IICG) dan dipublikasikan oleh Majalah SWA. Sistematika penilaian CGPI terdiri dari empat tahapan, yaitu self-assessment, sistem dokumentasi, penilaian makalah, dan observasi.

Populasi dalam penelitian ini adalah seluruh perusahaan yang terdaftar di BEI periode 2013-2016.Pengambilan sampel dalam penelitian ini menggunakan metode nonprobability sampling dengan teknik purposive sampling. 
Tabel 2.

Kriteria Pemilihan Sampel

\begin{tabular}{llc}
\hline No & \multicolumn{1}{c}{ Kriteria } & Jumlah \\
\hline 1 & Perusahaan yang terdaftar di Bursa Efek Indonesia & 603 \\
2 & Perusahaan yang tidak mengikuti pemeringkatan CGPI periode 2013-2016 & $(588)$ \\
3 & Perusahaan yang mengalami kerugian selama periode 2013-2016 & $(1)$ \\
Jumlah perusahan yang terpilih dijadikan sampel & 14 \\
Jumlah pengamatan penelitian & 56 \\
Total sampel penelitian & 56 \\
\hline Sumber: Data diolah, 2018 &
\end{tabular}

Pengujian ini bertujuan untuk menentukan hubungan antara dua variabel yang dipengaruhi oleh variabel moderasi. Pengujian Moderated Regression Analysis (MRA) dalam penelitian ini menggunakan uji nilai selisih mutlak dengan rumus persamaan regresi sebagai berikut.

$$
\mathrm{Y}=\alpha+\beta_{1} \mathrm{X}_{1}+\beta_{2} \mathrm{X}_{2}+\beta_{3} \mathrm{M}+\beta_{4}\left|\mathrm{X}_{1}-\mathrm{M}\right|+\beta_{5}\left|\mathrm{X}_{2}-\mathrm{M}\right|+\varepsilon
$$

Keterangan:

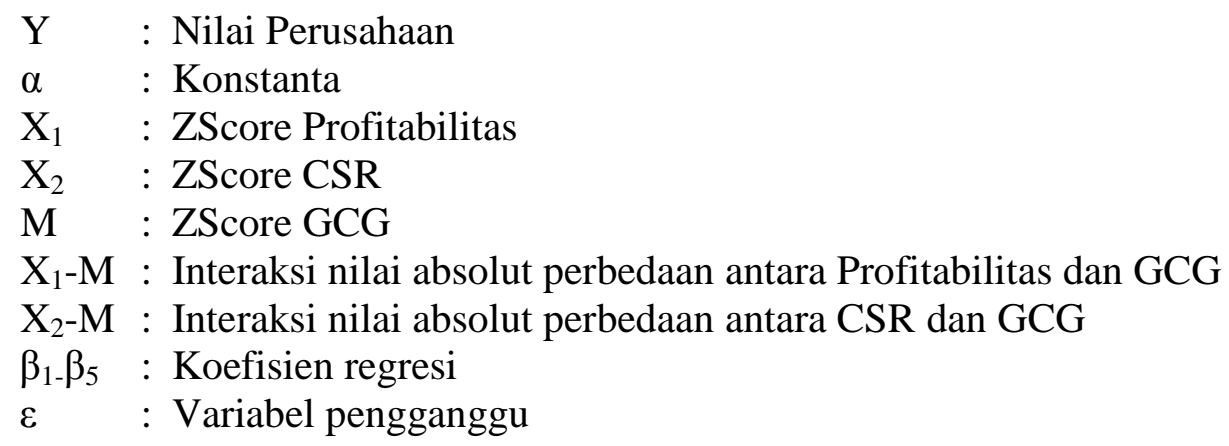

\section{HASIL DAN PEMBAHASAN}

Statistik deskriptif berhubungan dengan pengumpulan dan peringkat data yang menggambarkan karakteristik sampel yang digunakan dalam penelitian ini. Analisis ini berguna untuk menjelaskan karateristik sampel terutama mencakup nilai rata-rata (mean), nilai ektrim yaitu nilai minimum dan nilai maksimum, serta standar deviasi dari masing-masing variabel. Hasil dari statistik deskriptif tersebut dapat dilihat pada Tabel 3 berikut. 
Tabel 3.

Hasil Statistik Deskriptif

\begin{tabular}{lccccr}
\hline & N & Minimum & Maximum & Mean & $\begin{array}{c}\text { Std. } \\
\text { Deviation }\end{array}$ \\
\hline PBV & 46 & 0,56 & 4,79 & 2,1922 & 1,15015 \\
ROA & 46 & 1,00 & 17,44 & 5,4143 & 4,37924 \\
CSRDI & 46 & 1,01 & 1,57 & 1,2593 & 0,13002 \\
CGPI & 46 & 80,10 & 93,32 & 86,5559 & 3,27845 \\
Valid N (listwise) & 46 & & & &
\end{tabular}

Berikut penjelasan analisis statistik deskriptif masing-masing variabel berdasarkan Tabel 3 bahwa nilai perusahaan dalam penelitian ini diukur menggunakan rasio Price to Book Value (PBV). Berdasarkan Tabel 3 nilai ratarata PBV sebesar 2,1922 mendekati nilai maksimal sebesar 4,79 artinya rata-rata perusahaan memiliki kinerja yang baik dan mampu meningkatkan nilai perusahaan. Nilai standar deviasi sebesar 1,15015 lebih rendah dibandingkan nilai rata-rata. Hal ini menunjukkan bahwa sebaran data sudah merata atau perbedaan data satu dengan data yang lainnya tidak tergolong tinggi. Nilai minimum PBV sebesar 0,56 dimiliki oleh PT Aneka Tambang (Persero) Tbk. pada tahun 2015. Nilai maksimum PBV sebesar 4,79 dimiliki oleh PT Jasa Marga (Persero) Tbk. pada tahun 2014, dapat dikatakan bahwa perusahaan tersebut sudah mampu meningkatkan nilai perusahaannya.

Profitabilitas dalam penelitian ini diukur menggunakan rasio Return On Assets (ROA). Berdasarkan Tabel 3 nilai rata-rata ROA sebesar 5,4143 mendekati nilai maksimal sebesar 17,44 artinya rata-rata perusahaan memiliki kinerja yang baik dan mampu meningkatkan profitabilitas. Nilai standar deviasi sebesar 4,37924 lebih rendah dibandingkan nilai rata-rata. Hal ini menunjukkan bahwa sebaran data sudah merata atau perbedaan data satu dengan data yang lainnya 
I Putu Indra Wijaya dan Ni Gusti Putu Wirawati. Good ...

tidak tergolong tinggi. Nilai minimum ROA sebesar 1\% dimiliki oleh PT Aneka Tambang (Persero) Tbk. pada tahun 2016. Nilai maksimum ROA sebesar 17\% dimiliki oleh PT Telekomunikasi Indonesia (Persero) Tbk. pada tahun 2016, dapat dikatakan bahwa perusahaan tersebut memiliki profitabilitas yang baik.

Corporate Social Responsibiliy (CSR) dalam penelitian ini diukur menggunakan Corporate Social Responsibility Disclosure Index (CSRDI). Berdasarkan Tabel 3 nilai rata-rata CSRDI sebesar 1,2593 mendekati nilai maksimal sebesar 1,57 artinya rata-rata perusahaan sudah mengungkapkan CSR dengan baik. Nilai standar deviasi sebesar 0,13002 nilai ini lebih rendah dibandingkan nilai rata-rata. Hal ini menunjukkan bahwa sebaran data sudah merata atau perbedaan data satu dengan data yang lainnya tidak tergolong tinggi. Nilai minimum CSRDI sebesar 1,01 dimiliki oleh PT Bukit Asam Tbk. pada tahun 2016. Nilai maksimum CSRDI sebesar 1,57 dimiliki oleh PT Aneka Tambang (Persero) Tbk. pada tahun 2016, menunjukkan perusahaan sudah melakukan pengungkapan dengan maksimal.

Good Corporate Governance (GCG) dalam penelitian ini diukur menggunakan Corporate Governance Perception Index (CGPI). Berdasarkan Tabel 3 nilai rata-rata CGPI sebesar 86,5559 mendekati nilai maksimal sebesar 93,32 artinya rata-rata perusahaan sudah menerapkan GCG dengan baik. Nilai standar deviasi sebesar 3,27845 lebih rendah dibandingkan nilai rata-rata. Hal ini menunjukkan bahwa sebaran data sudah merata atau perbedaan data satu dengan data yang lainnya tidak tergolong tinggi. Nilai minimum CGPI sebesar 80,10 dimiliki oleh PT Timah Tbk. pada tahun 2013. Nilai maksimum sebesar 93,32 
dimiliki oleh PT Bank Mandiri (Persero) Tbk. pada tahun 2016, menunjukkan perusahaan sudah menerapkan GCG dengan maksimal.

Penelitian ini menggunakan Moderated Regression Analysis (MRA) dengan uji nilai selisih mutlak dalam model persamaan regresi linear berganda untuk mengetahui kemampuanGCG dalam memoderasi pengaruh profitabilitas dan CSR pada nilai perusahaan. Karena menggunakan uji nilai selisih mutlak sebelum diuji dilakukan perubahan bentuk data menjadi Z Score untuk variabel independen dan moderasi setelah dilakukan perubahan bentuk data selanjutnya mencari nilai selisih mutlak antara variabel independen dengan moderasi. Hasil uji MRA dari penelitian ini disajikan pada Tabel 4 berikut.

Tabel 4.

Hasil Uji Moderated Regression Analysis(MRA)

\begin{tabular}{|c|c|c|c|c|c|c|}
\hline \multicolumn{2}{|c|}{ Model } & \multicolumn{2}{|c|}{$\begin{array}{l}\text { Unstandardized } \\
\text { Coefficients }\end{array}$} & \multirow{2}{*}{$\begin{array}{c}\text { Standardized } \\
\text { Coefficients } \\
\text { Beta }\end{array}$} & \multirow[t]{2}{*}{$\mathbf{t}$} & \multirow[t]{2}{*}{ Sig. } \\
\hline & & B & $\begin{array}{l}\text { Std. } \\
\text { Error }\end{array}$ & & & \\
\hline \multirow[t]{10}{*}{1} & (Constant) & 0,244 & 0,056 & & 4,346 & 0,000 \\
\hline & Zscore(ROA) & 0,177 & 0,030 & 0,700 & 5,940 & 0,000 \\
\hline & Zscore(CSRDI) & 0,061 & 0,028 & 0,242 & 2,221 & 0,032 \\
\hline & Zscore(CGPI) & 0,031 & 0,026 & 0,121 & 1,184 & 0,244 \\
\hline & Selisih ROA dan CGPI & $-0,079$ & 0,039 & $-0,265$ & $-2,013$ & 0,051 \\
\hline & Selisih CSRDI dan & 0,100 & 0,047 & 0,265 & 2,133 & 0,039 \\
\hline & CGPI & & & & & \\
\hline & Adjusted $\mathrm{R}^{2}$ & 0,560 & & & & \\
\hline & $\mathrm{F}_{\text {hitung }}$ & 12,445 & & & & \\
\hline & Sig. F & 0,000 & & & & \\
\hline
\end{tabular}

Sumber: Data diolah, 2018

Berdasarkan hasil pengujian secara statistik yang ditunjukkan pada Tabel 4 maka persamaan regresi linier moderasi sebagai berikut.

$$
\mathrm{Y}=0,244+0,177+0,061+0,031-0,079+0,100+\varepsilon
$$

Berdasarkan persamaan diatas, dapat dijelaskan bahwa nilai konstanta 0,244 menunjukan bahwa bila profitabilitas, CSR dan GCG sama dengan nol, maka nilai 
I Putu Indra Wijaya dan Ni Gusti Putu Wirawati. Good ...

perusahaan akan meningkat sebesar 0,244 satuan dengan asumsi variabel lainnya konstan.

Nilai koefisien regresi ROA sebesar 0,177 menunjukan bahwa bila profitabilitasnaik satu satuan, maka nilai perusahaan akan mengalami peningkatan sebesar 0,177 satuan dengan asumsi variabel lainnya konstan.

Nilai koefisien regresi CSRDI sebesar 0,061 menunjukan bahwa bila CSR naik satu satuan, maka nilai perusahaan akan meningkat sebesar 0,061 satuan dengan asumsi variabel lainnya konstan.

Nilai koefisien regresi CGPI sebesar 0,031 menunjukan bahwa bila GCG naik satu satuan, maka nilai perusahaan akan meningkat sebesar 0,031 satuan dengan asumsi variabel lainnya konstan.

Nilai koefisien regresi ROA dan CGPI sebesar -0,075 menunjukan bahwa bila interaksi antara profitabilitasdengan GCGnaik satu satuan, maka nilai perusahaan akan mengalami penurunan sebesar 0,075 satuan dengan asumsi variabel lainnya konstan.

Nilai koefisien regresi CSRDI dan CGPI sebesar 0,100 menunjukan bahwa bila interaksi antara CSR dengan GCG naik satu satuan, maka nilai perusahaan akan mengalami peningkatan sebesar 0,100 satuan dengan asumsi variabel lainnya konstan.

Koefisien determinasi dalam penelitian ini dilihat melalui nilai adjusted $R$ square. Nilai dari adjustedR square pada penelitian ini telah disajikan pada Tabel 4. Berdasarkan pada Tabel 4 dapat dilihat bahwa nilai dari adjusted $R$ square sebesar 0,560 dimana memiliki arti bahwa 56\% variasi perubahan nilai perusahan 
dapat dijelaskan oleh variabel profitabilitas, CSR dan GCG. Sedangkan sisanya sebesar $44 \%$ dipengaruhi oleh variabel lain diluar dari model regresi yang digunakan.

Uji kelayakan model (Uji F) ini dilakukan untuk mengukur signifikansi secara serempak atau bersama-sama semua variabel independen terhadap variabel dependen. Hasil dari pengujian kesesuaian model dalam penelitian ini telah disajikan pada Tabel 4. Berdasarkan Tabel 4 dapat dilihat bahwa nilai dari uji $\mathrm{F}$ sebesar 12,445 dan nilai $p$-value (Sig. $F$ ) yakni0,000 lebih kecil dari nilai $\alpha=0,05$. Hal ini menunjukkan bahwa model persamaan dalam penelitian ini layak untuk digunakan.

Hipotesis pertama dalam penelitian ini menyatakan bahwa profitabilitas berpengaruh positif pada nilai perusahaan. Berdasarkan hasil analisis pengujian secara statistik dengan menggunakan Moderated Regression Analysis (MRA) diperoleh nilai koefisien regresi positif sebesar 0,177 dengan tingkat signifikansi sebesar 0,000 lebih kecil dari $\alpha=0,05$. Nilai positif artinya terjadi pengaruh positif antara profitabilitas dengan nilai perusahaan. Semakin tinggi profitabilitas perusahaan maka nilai perusahaan juga akan semakin tinggi. Hasil ini menunjukkan bahwa profitabilitas berpengaruh positif pada nilai perusahaan. Dengan demikian hipotesis pertama dalam penelitian ini diterima.

Hasil penelitian ini sejalan dengan hasil penelitian oleh Puspita (2018) menyatakan bahwa profitabilitas berbengaruh positif pada nilai perusahaan karena profitabilitas yang tinggi menunjukkan prospek perusahaan yang baik, sehingga investor akan merespon positif sinyal tersebut dan pada akhirnya dapat 
I Putu Indra Wijaya dan Ni Gusti Putu Wirawati. Good ...

meningkatkan nilai perusahaan. Selain itu hasil penelitian ini juga sejalan dengan hasil penelitian yang dilakukan Indasari (2018), Dewi (2018), Malino (2017) dan Rahman et al. (2017) menyatakan bahwa profitabilitas berpengaruh positif pada nilai perusahaan.

Hipotesis kedua dalam penelitian ini menyatakan bahwa Corporate Social Responsibility (CSR) berpengaruh positif pada nilai perusahaan. Berdasarkan hasil analisis pengujian secara statistik dengan menggunakan Moderated Regression Analysis (MRA) diperoleh nilai koefisien regresi positif sebesar 0,061 dengan tingkat signifikansi sebesar 0,032 lebih kecil dari $\alpha=0,05$. Nilai positif artinya terjadi pengaruh positif antara CSR dengan nilai perusahaan. Semakin tinggi pengungkapan CSR perusahaan maka nilai perusahaan juga akan semakin tinggi. Hasil ini menunjukkan bahwa CSR berpengaruh positif pada nilai perusahaan. Dengan demikian hipotesis kedua dalam penelitian ini diterima.

Hasil penelitian ini sejalan dengan hasil penelitian sebelumnya yang dilakukan oleh Sidhoum \& Serra (2017) menyatakan bahwa CSR berpengaruh positif pada nilai perusahaan. Semakin banyak item pengungkapan sosial yang diungkapkan bila diiringi dengan kualitas pengungkapan yang semakin baik, maka dapat meningkatkan nilai perusahaan. Selain itu hasil penelitian ini juga sejalan dengan hasil penelitian yang dilakukan Armika (2018), Citra (2017), Wulansari (2017) dan Ramadhani dkk. (2017) menyatakan bahwa CSR berpengaruh positif pada nilai perusahaan.

Hipotesis ketiga dalam penelitian ini menyatakan bahwa Good Corporate Governance (GCG) memperkuat pengaruh profitabilitas pada nilai perusahaan. 
Berdasarkan hasil analisis pengujian secara statistik dengan menggunakan Moderated Regression Analysis (MRA) diperoleh nilai koefisien regresi negatif sebesar -0,079 dengan tingkat signifikansi sebesar 0,051 lebih besar dari $\alpha=0,05$. Nilai negatif artinya terjadi pengaruh negatif GCG terhadap hubungan antara profitabilitas dan nilai perusahaan, namun karena tingkat signifikansi lebih besar dari 0,05 maka hasil tersebut tidak signifikan. Hasil ini menunjukkan bahwa GCG tidak berpengaruh terhadap hubungan antara profitabilitas dan nilai perusahaan. Dengan demikian hipotesis ketiga dalam penelitian ini ditolak.

Hasil penelitian ini sejalan dengan hasil penelitian sebelumnya yang dilakukan oleh Flowerini (2018). Pengaruh yangtidak signifikan ini bisa terjadi karenapada dasarnya manfaat yang dapatdirasakan dari penerapan GCG bersifatlong term atau jangka panjang, sedangkannilai profitabilitas merupakan ukurankinerja yang sifatnya periodik, dengandemikian pengaruhnya tidak dapat dilihatsecara langsung. Selain itu hasil penelitian ini juga sejalan dengan hasil penelitian yang dilakukan Syafrina (2017), Akmalia dkk. (2017) dan Erdianty \& Bintoro (2015) menemukan bahwa GCG tidak mampu memoderasi pengaruh profitabilitas pada nilai perusahaan.

Hipotesis keempat dalam penelitian ini menyatakan bahwa Good Corporate Governance (GCG) memperkuat pengaruh Corporate Social Responsibility (CSR) pada nilai perusahaan. Berdasarkan hasil analisis pengujian secara statistik dengan menggunakan Moderated Regression Analysis (MRA) diperoleh nilai koefisien regresi positif sebesar 0,100 dengan tingkat signifikansi sebesar 0,039 lebih kecil dari $\alpha=0,05$. Nilai positif artinya terjadi pengaruh positif GCG terhadap 
I Putu Indra Wijaya dan Ni Gusti Putu Wirawati. Good ...

hubungan antara profitabilitas dan nilai perusahaan dengan tingkat signifikansi lebih kecil dari 0,05 maka hasil tersebut signifikan. Hasil ini menunjukkan bahwa GCG mampu memperkuat hubungan antara CSR dan nilai perusahaan. Dengan demikian hipotesis keempat dalam penelitian ini diterima.

Hasil penelitian ini sejalan dengan hasil penelitian sebelumnya yang dilakukan oleh Retno (2017). Melalui pelaksanaan GCG maka mendorong perusahaan untuk terus meningkatkan aktivitas CSR perusahaan sehingga citra perusahaan meningkat. Semakin baik manajemen dalam mengelola perusahaan menyebabkan pengungkapan CSR semakin baik, sehingga nilai perusahaan semakin tinggi. Selain itu hasil penelitian ini juga sejalan dengan hasil penelitian yang dilakukan Fiona (2017), Latupono (2015), Isbandi (2014) dan Astiyani (2014) menemukan bahwa GCG dapat memperkuat pengaruh pengungkapan CSR pada nilai perusahaan.

Penelitian ini menghasilkan simpulan mengenai Good Corporate Governance (GCG) sebagai pemoderasi pengaruh profitabilitas dan Corporate Social Responsibility (CSR) pada nilai perusahaan. Hasil dalam penelitian ini diharapkan dapat memberikan informasi mengenai pentingnya meningkatkan profitabilitas, pengungkapan CSR dan penerapan GCG sehingga nantinya dapat meningkatkan nilai perushaan. Penelitian ini berhasil membuktikan teori sinyal yaitu jika semakin tinggi profitabilitas perusahaan dan diikuti dengan semakin banyaknya pengungkapan CSR yang dilakukan perusahaan maka akan memberikan sinyal positif kepada pemangku kepentingan yang pada akhirnya dapat meningkatkan nilai perusahaan. 
Penelitian ini diharapkan akan memberikan kontribusi positif bagi semua pihak khususnya pihak investor dan perusahaan. Bagi pihak perusahaan diharapkan untuk terus berusaha meningkatkan profitabilitas, pengungkapan Corporate Social Responsibility (CSR) dan penerapan Good Corporate Governance (GCG) dengan baik karena hal tersebut dapat memengaruhi nilai perusahaan. Bagi perusahaan yang belum mengungkapkan CSR secara optimal diharapkan agar dapat mengungkapkan CSR secara lebih optimal. Perusahaan juga diharapkan mengikuti pemeringkatan CGPI yang dilakukan oleh IICG karena pada saat ini perusahaan yang ikut dalam pemeringkatan CGPI setiap tahunnya hanya sebagian kecil dari keseluruhan perusahaan serta hanya beberapa perusahaan yang ikut berturut-turut setiap tahunnya. Bagi pihak investor dalam berinvestasi diharapkan memperhatikan rasio profitabilitas, pengungkapan CSR dan penerapan GCG perusahaan, karena dilihat dari koefisien determinasi sebesar $56 \%$ profitabilitas, CSR dan GCG dapat menjelaskan nilai perusahaan.

\section{SIMPULAN}

Berdasarkan hasil analisis dan pembahasan yang telah dipaparkan pada bab sebelumnya, didapatkan simpulan bahwa profitabilitas berbengaruh positif pada nilai perusahaan. Corporate Social Responsibility berpengaruh positif pada nilai perusahaan. Good Corporate Governance tidak berpengaruh terhadap hubungan antara profitabilitas dan nilai perusahaan. Good Corporate Governance memperkuat hubungan antara Corporate Social Responsibility dan nilai perusahaan. 
I Putu Indra Wijaya dan Ni Gusti Putu Wirawati. Good ...

Bagi perusahaan di Indonesia selain meningkatkan profitabilitas diharapkan untuk lebih bersungguh-sungguh dalam meningkatkan pengungkapan Corporate Social Responsibility (CSR) sesuai dengan standar yang ada dan menerapkan konsep Good Corporate Governance (GCG) dengan baik. Hal ini penting karena bagi pihak eksternal, dengan tingkat profitabilitas perusahaan yang baik dan didukung oleh pengungkapan CSR dan penerapan GCG dengan baik maka akan memberikan daya tarik tersendiri dan memberikan sinyal positif lalu pada akhirnya perusahaan akan dapat meningkatkan nilai perusahaannya.

Investor dalam mengambil keputusan dalam berinvestasi, sebaiknya tidak hanya melihat dari informasi keuangannya saja. Namun juga tetap melihat aspek non keuangan seperti pengungkapan Corporate Social Responsibility (CSR) dan penerapan Good Corporate Governance (GCG) yang dilakukan oleh perusahaan. Karena apabila perusahaan dengan faktor keuangan yang baik dan didukung dengan faktor non keuangan yang baik pula makan akan dapat meningkatkan nilai perusahaan sehingga hal tersebut dapat menjadi nilai tambah bagi perusahaan maupun investor.

Pelitian ini menggunakan rasio Return On Assets (ROA) untuk mengukur profitabiltas, Corporate Social Responsibility Disclosure Index (CSRDI) untuk mengukur Corporate Social Responsibility (CSR) dan Corporate Governance Perception Index (CGPI) untuk mengukur GoodCorporate Governance (GCG). Peneliti selanjutnya diharapkan menggunakan perhitungan yang berbeda khususnya dalam mengukur GCG karena adanya keterbatasan sampel yang didapatkan dengan menggunakan CGPI. Keterbatasan sampel dikarenakan hanya 
terdapat beberapa perusahaan yang mengikuti pemeringkatan CGPI. Selain itu peneliti selanjutnya juga dapat menambah periode pengamatan dan menggunakan variabel lain yang dapat memengaruhi nilai perusahaan.

\section{REFERENSI}

Akmalia, A., Dio, K., \& Hesty, N. (2017). Pengaruh kinerja keuangan terhadap nilai perusahaan dengan corporate social responsibility dan good corporate governance sebagai variabel pemoderasi (studi empiris pada perusahaan manufaktur di bursa efek indonesia periode 2010-2015). Jurnal Manajemen Bisnis, 8(2), 200-221.

Armika, A. A. A. M. (2018). Pengaruh pengungkapan tanggung jawab sosial pada nilai perusahaan dengan profitabilitas sebagai variabel pemoderasi. E-Jurnal Akuntansi Universitas Udayana, 22.1, 80-107.

Astiyani, M. N. (2014). Kemampuan corporate governance memoderasi pengaruh pengungkapan csr pada nilai perusahaan. E-Jurnal Akuntansi Universitas Udayana, 7(1), 235-249.

Badan Pusat Statistik. (2017). Laporan Perekonomian Indonesia 2017. Jakarta: CV Nario Sari.

Citra, K. R. (2017). Pengaruh kepemilikan institusional, kepemilikan manajerial, dan pengungkapan corporate social responsibility terhadap nilai perusahaan pada perusahaan manufaktur yang terdaftar di bursa efek indonesia. Jurnal Ilmiah Akuntansi Bisnis, 2(1).

Dewi, A. A. A. T. W. (2018). Pengaruh profitabilitas pada Nilai Perusahaan dengan corporate social responsibility sebagai variabel intervening. E-Jurnal Akuntansi Universitas Udayana, 22(2), 1557-1583.

Erdianty, R. W., \& Bintoro, I. (2015). Pengaruh kinerja keuangan terhadap nilai perusahaan dengan pengungkapan corporate social responsibility dan good corporate governance sebagai variabel pemoderasi (studi kasus di bursa efek indonesia periode 2010-2012). Jurnal Manajemen Bisnis, 6(2), 376-396.

Fiona, J. (2017). Pengaruh corporate soacial responsibility disclosure terhadap firm value dimoderasi oleh good corporate governance. JOM Fekon, 4(1), $1570-1582$. 
I Putu Indra Wijaya dan Ni Gusti Putu Wirawati. Good ...

Flowerini, M. (2018). Kemampuan good corporate governance pengaruh penghindaran pajak dan nilai terhadap nilai perusahaan. Jurnal Fakultas Ekonomi, 12(1).

Heder. (2017). Pengaruh kinerja keuangan terhadap nilai perusahaan dengan good corporate governance sebagai variabel pemoderasi. Jurnal Ilmu Dan Riset Akuntansi, 6(7), 309-321.

Imron, G. S., Hidayat, R., \& Alliyah, S. (2014). Pengaruh kinerja keuangan dan ukuran perusahaan terhadap nilai perusahaan. POTENSIO, 18(2), 82-93.

Inastri, M. A. (2017). Pengaruh penerapan good corporate governance dan pengungkapan corporate soial responsibility pada nilai perusahaan. E-Jurnal Akuntansi Universitas Udayana, 21(2), 1400-1429.

Indasari, A. P. (2018). Pengaruh profitabilitas, growth opportunity, likuiditas , dan struktur modal pada nilai perusahaan. E-Jurnal Akuntansi Universitas Udayana, 22(1), 714-746.

Isbandi, B. R. (2014). Pengaruh kepemilikan manajerial sebagai variabel pemoderasi pada hubungan corporate social responsibility terhadap kinerja keuangan perusahaan (studi empiris pada perusahaan manufaktur yang terdaftar di bursa efek indonesia). Artikel Ilmiah Mahasiswa, 1-6.

Jensen, M. C., \& Meckling, W. H. (1976). Theory of the firm: managerial behavior, agency costs and ownership structure. Journal of Financial Economics, 3, 305-360.

Jitmaneeroj, B. (2018). A latent variable analysis of corporate social responsibility and firm value. Managerial Finance, 44(4), 478-494.

Kemala, A., Sudarma, M., \& Purnomosidhi, B. (2016). Pengaruh corporate social responsibility terhadap nilai perusahaan dengan ukuran perusahaan dan jumlah dewan komisaris sebagai variabel pemoderasi. Jurnal Aplikasi Manajemen, 14(2), 344-358.

Krenn, M. (2016). Understanding decoupling in response to corporate governance reform pressures the case of codes of good corporate governance. Journal of Financial Regulation and Compliance, 23, 369-382.

Kusumayanti, N. K. R. (2016). Corporate social responsibility sebagai pemoderasi pengaruh ukuran perusahaan, profitabilitas dan leverage pada nilai perusahaan. E-Jurnal Akuntansi Universitas Udayana, 15(1), 549-583.

Latupono, S. S. (2015). Pengaruh corporate social responsibility terhadap nilai perusahaan: good corporate governance variabel moderating. Jurnal Ilmu \& 
Riset Akuntansi, 4(8), 1-15.

Malik, A. (2018). Pengaruh struktur modal dan profitabilitas terhadap nilai perusahaan pada perusahaan keramik porselin dan kaca listing di bursa efek indonesia. JOM FISIP, 5(1), 1-12.

Malino, M. R. Y. D. (2017). Pengaruh profitabilitas dan kepemilikan manajerial pada nilai perusahaan dengan pengungkapan $\mathrm{csr}$ sebagai variabel pemoderasi. E-Jurnal Akuntansi Universitas Udayana, 21(3), 2052-2080.

Maqbool, S., \& Zameer, M. N. (2018). Corporate social responsibility and financial performance: an empirical analysis of indian banks. Future Business Journal, 4(1), 84-93.

Maulana, A. (2016). Pengaruh kinerja keuangan terhadap nilai perusahaan dengan mekanisme good corporate governance sebagai variabel moderasi. JOM Fekom, 3(1), 993-1005.

Mawati, E. R., Hardiningsih, P., \& Srimindarti, C. (2017). Corporate governance memoderasi earning management dan profitabilitas terhadap nilai perusahaan. Prosiding Seminar Nasional Multi Disiplin Ilmu \& Call For Papers Unisbank, 3, 519-528.

Muliani, L. E., Yuniarta, G. A., \& Sinarwati, K. (2014). Pengaruh kinerja keuangan terhadap nilai perusahaan dengan pengungkapan corporate social responsibility dan good corporate governance sebagai variabel pemoderasi (studi kasus di bursa efek indonesia periode 2010-2012). E-Journal S1 Akuntansi Universitas Pendidikan Ganesha, 2(1), 23-33.

Nègre, E., Verdier, M. A., Cho, C. H., \& Patten, D. M. (2017). Disclosure strategies and investor reactions to downsizing announcements: a legitimacy perspective. Journal of Accounting and Public Policy, 239-257.

Oktaviana, L. L. (2017). Pengaruh kepemilikan saham dan corporate social responsibility terhadap agresivitas pajak. Jurnal Ilmu Dan Riset Akuntansi, 6(11), 1-20.

Permana, I. P. D. (2017). Pengaruh karakteristik perusahaan dan kepemilikan institusional pada nilai perusahaan dengan csr sebagai variabel intervening. E-Jurnal Akuntansi Universitas Udayana, 21(2), 1263-1289.

Puspita, N. K. D. (2018). Pengungkapan tanggung jawab sosial memoderasi pengaruh profitabilitas dan ukuran perusahaan pada nilai perusahaan. $E$ Jurnal Akuntansi Universitas Udayana, 22(3), 2148-2176. 
Putri, I. G. A. M. A. D., \& Ulupui, I. G. K. A. (2017). Pengantar Corporate Governance. Denpasar: cv.sastra utama.

Rahman, M. H., Ibrahim, M. Y., \& Ahmad, A. C. (2017). Accounting profitability and firm market Valuation: a panel data analysis. Global Business and Management Research: An International Journal, 9(1), 679-690.

Ramadhani, A. R., Purnamawati, I. G. A., \& Sujana, E. (2017). Pengaruh corporate social responsibility dan kepemilikan manajerial terhadap nilai perusahaan dengan profitabilitas sebagai variabel moderating. Sl $A k$ Universitas Pendidikan Ganesha, 7(1).

Retno, D. (2017). Pengaruh csr dan enviromental performance terhdap nilai perusahaan dengan gcg variabel moderating. Jurnal Ilmiah Dan Ilmu Akuntansi, 6(11), 1-24.

Ross, S. A., Westerfield, R. W., Jordan, B. D., Lim, J., \& Tan, R. (2016). Fundamental of Corporate Finance (Second). New York: McGraw-Hill Education.

Sidhoum, A. A., \& Serra, T. (2017). Corporate social responsibility and dimensions of performance: an application to u.s electric utilities. Utilities Policy, 1-11.

Sulistyaningsih, S., Wijayanti, A., \& Masitoh, E. (2017). Pengaruh corporate social responsibility terhadap nilai perusahaan dengan profitabilitas sebagai variabel moderating. Seminar Nasional IENACO, 787-794.

Syafrina, W. (2017). Faktor-faktor yang mempengaruhi koefisien respon laba pada perusahaan manfaktur yang terdaftar di bei. Jurnal Akuntansi, 6(2), $194-210$.

Triyana, M. (2017). Pengaruh profitabilitas dan keputusan investasi terhadap nilai perusahaan pulp \& paper yang terdaftar di bursa efek indonesia. Jom FISIP, $4(2), 1-12$.

Undang-Undang Republik Indonesia Nomor 40 Tahun 2007 Tentang Perseroan Terbatas.

Warrad, L. H., \& Nassar, M. (2017). Could profitability, activity and use of equity finance increasing duPont model of return on equity? jordanian case. International Review of Management and Marketing, 7(3), 35-41.

Wulansari, R. (2017). Pengaruh corporate social responsibility dan good corporate governance terhadap nilai perusahaan. Jurnal Ilmu Dan Riset Akuntansi, 6(8), 1-19. 